\title{
Leaf Blade Anatomy of Philippine Medinilla Gaudich. Species in Relation to their Epiphytic Habit
}

\author{
ANTONIO L. RAYOS, JR. \\ ORCID No. 0000-0003-4114-9867 \\ alrayos@up.edu.ph \\ University of the Philippines Los Baños \\ Laguna, Philippines \\ ANNALEE S. HADSALL \\ ORCID No. 0000-0002-8884-3904 \\ annalee.hadsall@gmail.com \\ University of the Philippines Los Baños \\ Laguna, Philippines
}

\begin{abstract}
Leaf anatomy of four epiphytic species of Philippine Medinilla, namely, $M$. magnifica Lindl., M. miniata Merr., M. pendula Merr., and M. teysmannii Miq., was characterized by observation of leaf cross sections prepared through paraffin method. Similarities among the four species revealed by this study include thick hypodermis below the upper epidermis, palisade mesophyll comprising one layer of elongated lignified parenchyma cells, spongy mesophyll with scarce air spaces, and polocytic stomates present only in the lower epidermis. These features aid in water conservation which is highly crucial among epiphytes. Presence of druse crystals in all four species was observed. This feature functions for structural support, defense against herbivory, calcium storage, and increasing photosynthetic efficiency. In hypodermis, number of cell layers, cell shape, and relative thickness vary among the four species in this study. The spongy mesophyll of the four species differ in number of cell layers. Because these variations can differentiate these species from one another, they are deemed to be useful in taxonomy. This
\end{abstract}


study shows that anatomical features of the Medinilla species used in this study are related to their epiphytic nature and their occurrence in the forest understory.

Keywords: Medinilla, epiphyte, sclerified mesophyll, hypodermis, druse, polocytic stomates

\section{INTRODUCTION}

The definition of the term "epiphyte" is restricted to vascular plants that grow on other plants (usually trees) without getting nutrients from them (Benzing 1984). Epiphytism is widely distributed among several taxonomic groups of angiosperms including a few members of families Araceae, Asclepiadaceae, Bromeliaceae, Gesneriaceae, Melastomataceae, Nepenthaceae, Orchidaceae, and Piperaceae.

The abundance of epiphytes in tropical rainforests is associated with the supply of moisture and nutrient in the forest canopy (Grime 2001). Due to their habit, they are subjected to a shortage of water supply like dessert plants (Gurevitch, Scheiner, and Fox 2006). Even in tropical forests like the Philippines where rainfall is high, dry conditions are surprisingly present in high canopy. For that reason, epiphytes need adaptations for interception and retention of water as well as minerals (Benzing 1984).

Medinilla Gaudich. is a paleotropical genus of flowering plants that includes epiphytic and terrestrial shrubs as well as climbers (Regalado 1995). Out of 400 species belonging to the genus, at least 80 species are found within the Philippine archipelago (about 90 percent of which are endemic). M. magnifica, M. miniata, $M$. pendula, and M. teysmannii are among the species that exhibit epiphytism in the wild.

Reports on leaf anatomy of some Medinilla species include hypodermis occupying half the thickness of the lamina, one-layered palisade mesophyll with sclerified cells, spongy mesophyll cells with local thickenings, and caryophyllaceous stomata (Metcalfe and Chalk 1950). Druse crystals were observed in the leaves of M. cauliflora, M. mirabile, and M. speciosa (Mentink and Baas 1992). Mesophyll sclereids were also reported on $M$. cauliflora. 


\section{OBJECTIVES OF THE STUDY}

This study aimed to analyze the anatomical characteristics of the leaves of selected species of Philippine Medinilla in relation to their epiphytic habit.

\section{MATERIALS AND METHODS}

\section{Collection of Specimens}

Fresh leaf samples of the four species of Medinilla, namely, M. magnifica Lindl., M. miniata Merr., M. pendula Merr., and M. teysmannii Miq. were obtained from the greenhouse of the Institute of Plant Breeding, College of Agriculture, University of the Philippines Los Baños, College, Laguna. Taxonomic identification was made by the staff of the Botanical Herbarium CAHUP, Museum of Natural History, University of the Philippines Los Baños.

\section{Characterization of Foliar Anatomy}

For each species, a mature leaf was obtained and a rectangular portion (about $3 \times 5 \mathrm{~mm}$ ) near the midrib was cut. These were fixed in formalin-acetic acid-ethyl alcohol (FAA) solution for 24 hours, and then subjected to alcohol dehydration series. The dehydrated leaves were then gradually infiltrated with paraffin prior to paraffin embedding. The samples were mounted on a wooden block and sectioned ( $5 \mu \mathrm{m}$ thick) using rotary microtome. The thin sections were rehydrated and stained with Safranin and Fast Green FCF. Destaining was done by subjecting the samples to xylene-aniline series, and then mounting on glass slides were done using Canada balsam. The prepared slides were observed under light microscope and then photographed. Anatomical characteristics were then observed.

Epidermal imprinting was done to observe stomatal morphology. Nail polish was thinly applied on both leaf surfaces, and then after drying, the transparent tape was pressed into the nail polished layer. The imprint was removed, transferred to a clean glass slide, and observed under light microscope. Stomatal type and position were determined.

\section{RESULTS AND DISCUSSION}

Microscopic observations revealed similarities and differences in the leaf blade anatomy of the four epiphytic species of Medinilla in this study. Plate 1 shows the transverse sections of their leaf blades. In all cases, thick hypodermis below one 
cell layer of upper epidermis was seen, varying in the number of layers of closely packed cells. The hypodermis is described as a tissue having few or no chloroplasts (Esau 1977). This layer resembles multiple epidermises but originates from the ground meristem (Evert 2006). Leaf hypodermis, having various functions including storage of water, is a prominent xeromorphic feature of mangroves (Baylis 1940; Saenger 2002). It was observed in at least five families of epiphytic plants that water accumulates in the Adaxial hypodermis which expands and later on transfers its contents to neighboring young leaves (Benzing 2012). In pines, the hypodermis adjacent to the epidermis is made up of sclerenchymatous cells which, according to Larcher (1995), aids in limiting uncontrolled transpiration (as cited in Grill, Tausz, and Pollinger 2004).

Variation was observed in the hypodermis of the four species of Medinilla in terms of number of cell layers, the shape of cells, and relative thickness. The differences in the hypodermis of the four species are shown in Table 1. These differences could be useful in distinguishing these species from one another.

Table 1. Comparison among the Hypodermis of the Four Epiphytic Species of Medinilla Considered in this Study

\begin{tabular}{|c|c|c|c|c|}
\hline Species & $\begin{array}{c}\text { Number of } \\
\text { cell layers }\end{array}$ & $\begin{array}{c}\text { Shape of cells close } \\
\text { to upper epidermis }\end{array}$ & $\begin{array}{c}\text { Shape of cells adjacent } \\
\text { to palisade mesophyll }\end{array}$ & Relative thickness \\
\hline M. magnifica & $4-5$ & polygonal & oblong & about half of the lamina \\
\hline M. pendula & $2-3$ & cuboidal & oblong & more than half of the lamina \\
\hline M. miniata & $6-7$ & polygonal & oblong & more than half of the lamina \\
\hline M. teysmannii & $3-4$ & cuboidal & cuboidal & about half of the lamina \\
\hline
\end{tabular}

The palisade mesophyll comprises one layer of elongated and lignified parenchyma. This feature is for additional support as well as prevention of water loss. Water from the hypodermis cannot easily pass through this layer due to the water-proof lignin. Although the presence of secondary wall distinguishes sclerenchyma cells from parenchyma and collenchyma cells, it is possible for ground parenchyma cells to develop secondary walls as well (Esau 1965). Such parenchyma cells are termed as "sclerotic parenchyma" by Bailey and Swamy (1949). Air spaces in spongy mesophyll layer are relatively few, and this feature probably prevents water loss. 

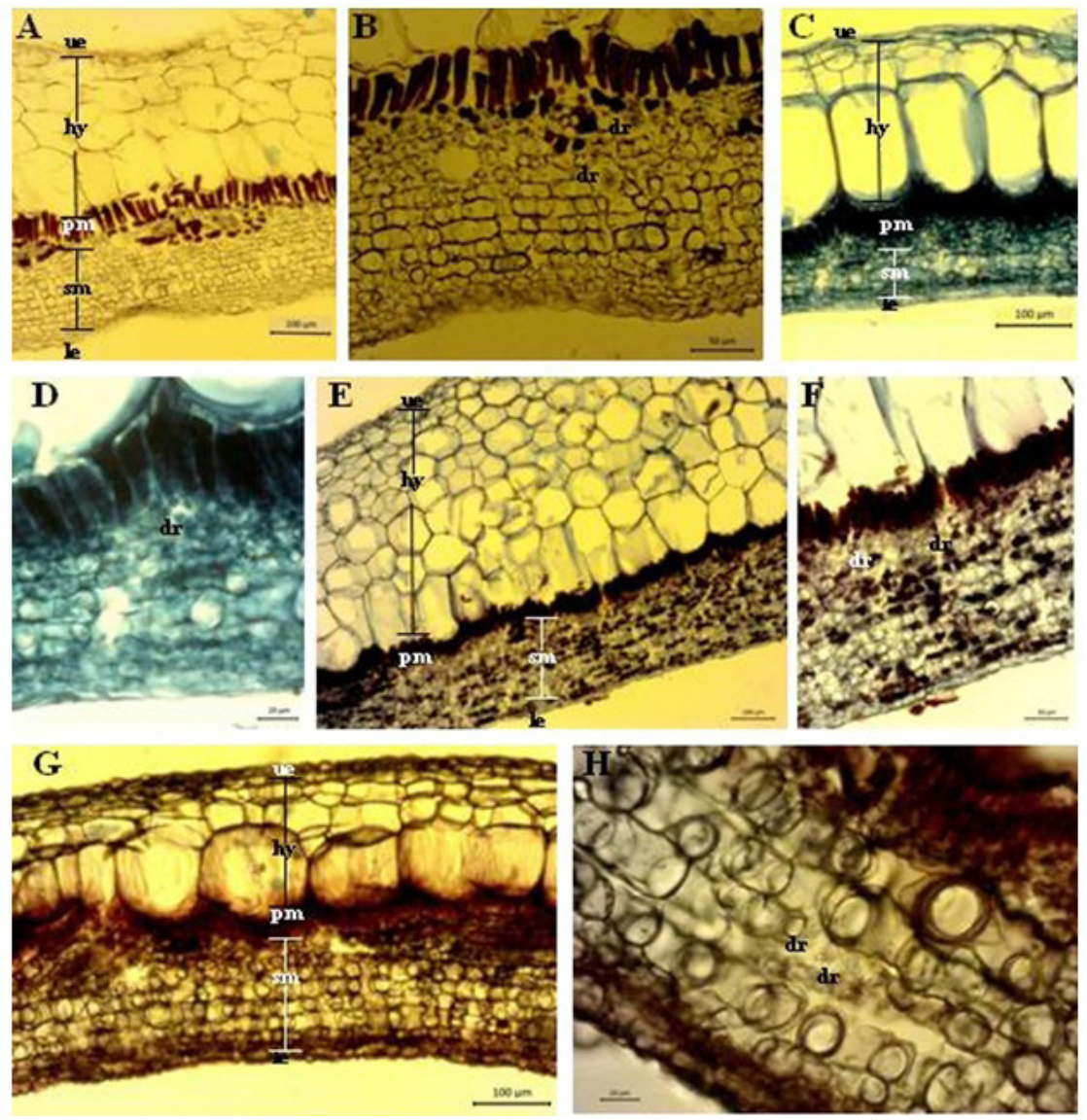

Plate 1. The Cross Sections of the Lamina of (A and B) M. magnifica, (C and D) M. pendula, (E and F) M. miniata, and ( $\mathrm{G}$ and $\mathrm{H})$ M. teysmannii

Showing the Upper Epidermis (ue), Thick Hypodermis (hy), Lignified Palisade Mesophyll (pm), Spongy Mesophyll (sm), Lower Epidermis (le), and Druse Crystals (dr).

The spongy mesophyll layer in the four species has spherical to oblong cells but differs in the number of cell layers. In $M$. magnifica, there are 10-11 layers of cell in this tissue; $M$. pendula, 7-8; M. miniata, 6-7; and M. teysmannii, 5-6. The lower epidermis was seen as one layer of cells. 
Polocytic stomates, which are characterized by two guard cells sharing one subsidiary cell (Wing, Ash, Ellis, Hickey, Johnson, and Wilf 1999), are present only in the abaxial side as shown in Plate 2 . The stomatal position possibly aids in water conservation.

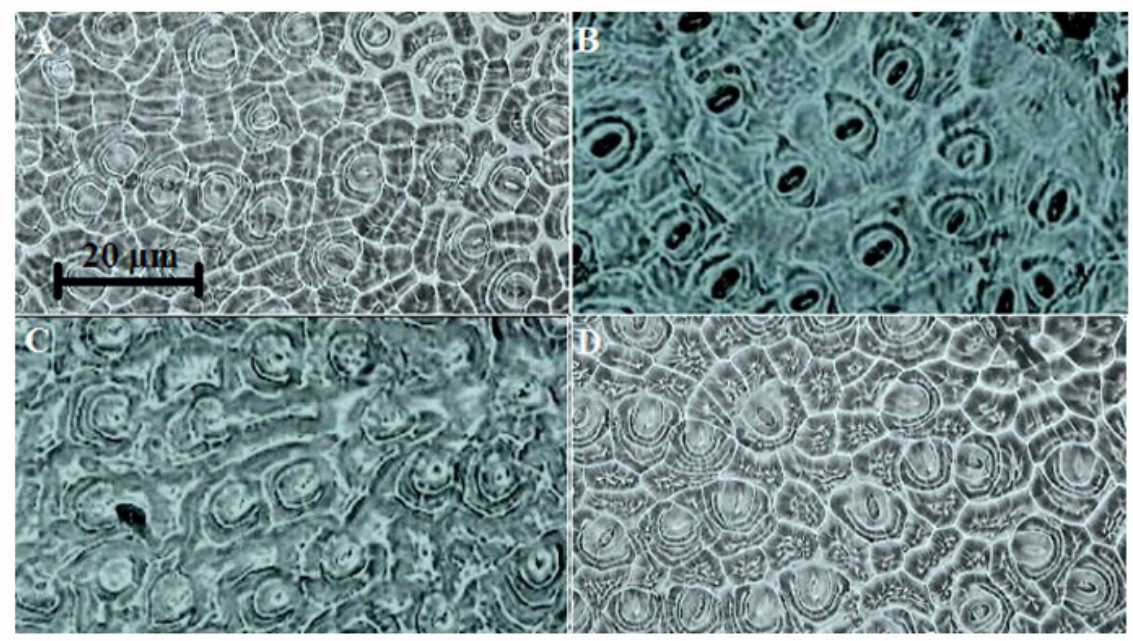

Plate 2. The Epidermal Imprints of the Abaxial Sides of the Leaves of (A) M. magnifica, (B) M. pendula, (C) M. miniata, and (D) M. teysmanni. Showing Polocytic Stomates.

The presence of druses, which are calcium oxalate crystals, (Plates 1B, 1D, 1F, and $1 \mathrm{H}$ ), was observed in the spongy mesophyll cells of all four species. The study of Horner (2012) suggests that druse crystals in the photosynthetic tissue can collect and disperse light to the surrounding chloroplasts. This is associated with the occurrence of these Medinilla species in the forest understory. These crystals have regulatory roles in the calcium level of the cells, and excess calcium can be accumulated as calcium oxalate to be remobilized under particular conditions (Volk, Lynch-Holm, Kostman, Goss, and Franceschi 2002). This partly answers the mineral procurement problems being encountered by epiphytes. Calcium oxalate crystals also function for structural support and defense against herbivores (Franceschi and Horner 1980).

Water conservation is important in epiphytes because being attached to trees or other plants renders water shortage as rainwater is not retained in tree trunks. 
The leaf anatomical features observed in this study are manifestations of the evolutionary response of the Medinilla species to their epiphytic habitat. On the other hand, the observed differences in the hypodermis and spongy mesophyll tissues of the four species in this study are useful in differentiating these species from one another.

\section{CONCLUSIONS AND RECOMMENDATIONS}

All four species exhibited similar patterns of leaf anatomy that have adaptive significance related to epiphytic habit. There are also differences in the leaf anatomy of these four species, and these could be useful in taxonomy. The findings in this study will contribute to understanding epiphytic adaptations of plants native to the Philippine archipelago and also in taxonomic studies on this genus. It will prove to be very important in making decisions regarding conservation. It is recommended that anatomical studies on other organs like root and stem must also be conducted for further investigation of the epiphytic adaptations of the Medinilla species. It is further recommended that other species of Medinilla including non-epiphytic species should be considered for a more thorough anatomical survey that could aid in the taxonomy of this genus.

\section{LITERATURE CITED}

Bailey IW, Swamy BGL. 1949. The morphology and relationships of Austrobaileya. J Arnold Arbor 30: 211-226.

Baylis GTS.1940. Leaf anatomy of the New Zealand Mangrove. T Roy Soc NZ Bot 70: 164-170.

Benzing DH. 1984. Epiphytic vegetation: A profile and suggestions for future inquiries. In Medina, E., H.A. Mooney, and C. Vasquez-Yanes (Eds.). Physiological ecology of plants of the wet tropics., The Hague: Dr. W. Junk Publishers. pp. 155-171.

Benzing DH. 2012. Air plants: Epiphytes and aerial gardens. Ithaca: Cornell University Press. 256 p. 
Esau K. 1965. Plant anatomy (2nd ed.). New York: John Wiley and Sons, Inc. $767 \mathrm{p}$.

Esau K. 1977. Anatomy of seed plants (2nd ed.). New York: John Wiley and Sons, Inc. 576 p.

Evert RF. 2006. Esau’s plant anatomy (3rd ed.). Hoboken: John Wiley and Sons, Inc. $624 \mathrm{p}$.

Franceschi VR, Horner HT. 1980. Calcium oxalate crystals in Plants. Bot Rev 46(4): 361-427.

Grill D, Tausz M, Pollinger U, Jimenez MS, Morales D. 2004. Effects of drought on needle anatomy of Pinus canariensis. Flora 199: 85-89.

Grime JP. 2001. Plant strategies, vegetation processes, and ecosystem properties. 2nd ed. Cnichester: John Wiley and Sons Ltd. 456 p.

Gurevitch J, Scheiner SM, Fox GA. 2006. The ecology of plants. 2nd ed. Sunderland: Sinauer Associates Inc. 518 p.

Horner HT. 2012. Peperomia leaf cell wall interface between the multiple hypodermis and crystal-containing photosynthetic layer displays unusual pit fields. Ann Bot 109: 1307-1315.

Larcher W. 1995. Physiological plant ecology. 3rd ed. New York: Springer-Verlag. $506 \mathrm{p}$.

Mentink H, Baas P. 1992. Leaf anatomy of the Melastomataceae, Memecylaceae, and Crypteroniaceae. Blumea 37: 189-225.

Metcalfe CR, Chalk L. 1950. Anatomy of the dicotyledons (Vol. 1). Oxford: Oxford University Press. 802 p.

Regalado C Jr. 1995. Revision of Philippine Medinilla (Melastomataceae). Blumea 40: 113-193. 
Saenger P. 2002. Mangrove ecology, silviculture, and conservation. Dordretch: Kluwer Academic Publishers. 360 p.

Volk GM, Lynch-Holm V, Kostman GA, Goss LJ, Franceschi VR. 2002. The role of druse and raphide calcium oxalate crystals in tissue calcium regulation in Pistia stratiotes leaves. Plant Biol 4(1): 34-45.

Wing S,Ash A, Ellis B, Hickey L, Johnson K., Wilf P. 1999. Manual of leaf architecture: Morphological description and categorization of dicotyledonous and net-veined monocotyledonous angiosperms. Washington, D.C.: Smithsonian Institution. 67 p. 